\title{
PERCEPTIONS OF CRUCIFIXION AMONG JEWS AND CHRISTIANS IN THE ANCIENT WORLD $^{1}$
}

\author{
David W. Chapman
}

This thesis explores the perceptions of crucifixion among Jewish people in the period from Alexander the Great until Constantine. Earlier similar studies concentrate on Graeco-Roman literature or limit discussion to whether certain Jews favoured the penalty of crucifixion. This dissertation, in contrast, examines Jewish literature in order to demonstrate the range of early Jewish perceptions about crucifixion. Early Christianity reflects awareness of, and interaction with, these Jewish perceptions.

The first chapter begins by surveying contemporary research on crucifixion in ancient Jewish sources. Then follows an extensive analysis of Latin, Greek, Hebrew, Aramaic and Syriac terminology for crucifixion. Each of these ancient languages manifests similar application of crucifixion terminology, often employing the same words for ante-mortem suspension on a cross-shaped object (i.e. crucifixion) as they do for post-mortem hangings or for ante-mortem suspensions in a variety of postures. Most frequently the actual method of execution apparently did not concern ancient authors. And the linguistic evidence implies that crucifixion was a subset of the many ancient forms of penal human bodily suspension. Therefore, the study of Jewish perceptions of all forms of human bodily suspension in antiquity can inform the more narrow question about how crucifixion was perceived by Jewish peoples. This chapter also contains a demonstration that, despite recent controversy, the semantic ranges of Hebrew של מתב תלה (and their nominal cognates and Aramaic equivalents) include the notion of 'crucify' in post-biblical Jewish literature.

The next three chapters inductively scrutinise Jewish texts which speak of human bodily suspension. Chapter Two examines texts

1 David W. Chapman, Perceptions of Crucifixion among Jews and Christians in the Ancient World (unpublished Ph.D. thesis, University of Cambridge, 2000); supervisor: Professor William Horbury. 
which claim to report historical crucifixion events in the Second Temple and early rabbinic periods. The ANE was long familiar with execution by suspension, and this was continued into the Hellenistic period in Palestine. Significantly, Josephus and the Assumption of Moses both portray the Maccabean martyrs under Antiochus Epiphanes as crucified. Josephus also claims that the Hasmonean king Alexander Jannaeus practised mass crucifixion against his countrymen (possibly also reflected in the Qumran Nahum Pesher). Rabbinic traditions about Simeon ben Shetach indicate that even a great Jewish sage could be said to execute evildoers (i.e. witches) by suspension.

Both Josephus and Philo present graphic accounts of multiple crucifixions under the Romans. The victims (especially brigands and rebels) are often considered justly punished. Yet, on other occasions the crucified are viewed as innocent sufferers. Archaeological evidence from Giv'at ha-Mivtar confirms such crucifixions occurred and points to some degree of sympathy given to the deceased. Rabbinic anecdotes include laments about Jewish martyrs who face the cross (even long after the First Revolt). A surprising account, however, claims that Rabbi Eleazar assisted in delivering brigands to the Roman cross.

The Hebrew Bible records narratives and laws related to bodily suspension. Chapter Three examines how later Jewish tradition increasingly associated these texts with crucifixion and death by suspension. Philo and Josephus depict Pharaoh's baker in Genesis 40-41 as crucified (cf. also the Targumim). And rabbinic and targumic literature portrays the penalty in Numbers $25: 4$ and in 2 Samuel 21:6, 9,13 as prolonged bodily hanging.

Although Deuteronomy 21:22-23 apparently concerns limitations on Jewish practice of post-mortem suspension (as highlighted by rabbinic tradition), the Temple Scroll, Philo and the Peshițta attest that some considered this text to prescribe an executionary form. Further, Josephus, Philo and a parable attributed to Rabbi Meir specifically associated Deuteronomy 21 with crucifixion. With regard to Deuteronomy 21:23, post-biblical Jewish literature connected the genitive in the 'curse of God' (קללת אלהים) construct either with a cursing of the suspended person or with his blasphemy of God.

Haman's death in Esther best exemplifies the suspension of an evildoer on a wooden object in the Old Testament. The two Greek recensions of Esther specifically apply crucifixion terms to Haman's execution (cf. Josephus). Further, targumic and rabbinic accounts of 
Haman's demise employ the standard terminology for a death by suspension, sometimes with clear overtones of crucifixion. Crucifixion associations are also found in later Jewish traditions on Lamentations 5:12-13 and Ezra 6:11.

Since Jewish tradition from the Second Temple and rabbinic periods frequently connected biblical texts involving human bodily suspension with crucifixion, these texts provided a number of (largely negative) biblical exemplars of hung/crucified people and also associated the 'curse of God' with a person suffering such a penal suspension.

Chapter Four collects proverbial stories and possible images of crucifixion. Philo utilises crucifixion to create horribly vivid images. Rabbinic anecdotes similarly employ stories of crucified people (especially brigands), often without sympathy for their plight. Indeed, God may even be portrayed as the analogue of the crucifier. Nonetheless, in a few places crucifixion was associated with the binding of Isaac and with the roasting of the paschal lamb. These likely represent two Jewish 'latent images' (images not necessarily initially connected with crucifixion, but which later could be used as figures of the cross by Christians and Jews).

Chapter Five summarises the perceptions of crucifixion by surveying tendencies in literary groupings and by making some general observations. Early Jewish sources frequently link crucifixion with the deaths of brigands, rebels and magicians, often considering these executions well-deserved. The sources also testify to the shamefulness and horror of the cross. Biblical exemplars of deaths by suspension are usually negative figures, and Deuteronomy 21 connects the death of the person so suspended with the 'curse of God' (be that blasphemy or a cursing by God). However, in some historical narratives crucified people were portrayed as innocent sufferers, or even as martyrs. While many of these perceptions are not exclusive to Jewish people in the Graeco-Roman world, some of the associations with suffering and martyrdom had particular reference to the plight of Jews. And, certainly biblical associations would have helped create distinctively Jewish views of crucifixion.

The concluding chapter, focusing on New Testament texts and works adversus Iudaeos, argues that early Christian communities interacted with these Jewish perceptions of the cross. New Testament writers and other early Christian authors refute Jewish accusations that Jesus' crucifixion should be associated with brigandage, magic and blasphemy. Further, Jesus' death was likely 
connected by some Jews with the shameful execution of Haman-a charge that receives strong rebuttal in Christian adversus Iudaeos works. Whereas in Christian writings beginning with the New Testament the shame and curse of the cross is affirmed (for purposes such as motivating obedience, encouraging repentance, or depicting the salvific work of Christ), adversus Iudaeos works often evidence an apologetic attempt to side-step Jewish appeals to shame and cursing in the cross of Christ.

Previous studies have rightly demonstrated how pervasive in antiquity was the view of the cross as a terrible and shameful death. This thesis provides further evidence that such views were taken in ancient Jewish communities. In addition, an attempt is made to complement this view by indicating that more positive perceptions could also be attached to crucifixion insofar as the death could be associated with the innocent sufferer or martyr as well as with latent sacrificial images. Christian writers, proclaiming Christ crucified, betray awareness of all these various perceptions by seeking to reject or transform negative stereotypes, or by embracing some of the more positive Jewish perceptions of the cross in antiquity. 